\title{
Influence of a newly-synthesised 5-oxo-1,2,4-triazyne derivative on antioxidant indices of blood and performance of turkey hens
}

\author{
K. Ognik ${ }^{\#}$ I. Sembratowicz \\ Department of Biochemistry and Toxicology, Faculty of Animal Biology and Breeding, University of Life Sciences, \\ 20- 950 Lublin, Poland
}

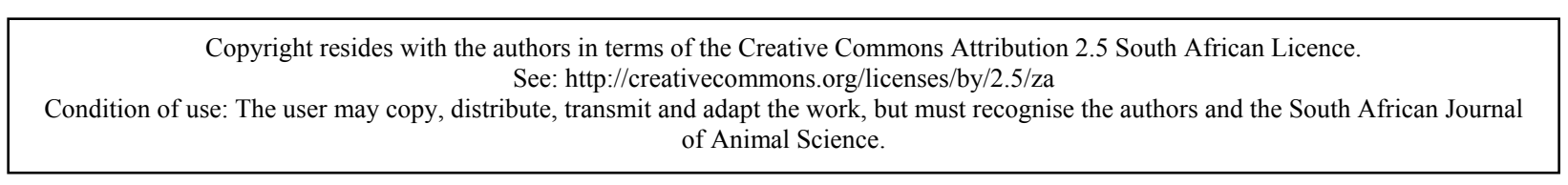

\begin{abstract}
The aim of the study was to evaluate the influence of a newly-synthesised 5-oxo-1,2,4-triazyne derivative on the antioxidant status and performance of turkey hens. The experiment was conducted on sixweek old Big- 6 turkey hens, divided equally into four groups (60 birds/group). The treatments were: T0 control (no triazyne supplement) and T15, T30, T45: 5-oxo-1,2,4-triazyne supplementation at 15, 30 and 45 $\mu \mathrm{g} / \mathrm{kg} \mathrm{BW} /$ day, respectively. The additive was administered over a period of eight weeks. A two-week break with no triazyne supplementation was given in the middle of that period. The performance indices were body weight, feed conversion ratio and the Index of Rearing Effectiveness (WEO). The antioxidant parameters were superoxide dismutase, glutathione peroxidase and catalase activity in erythrocytes and copper, iron and zinc concentrations in plasma. None of these measurements were affected by any of the supplementation treatments. However, after four weeks the supplementation of the 5-oxo-1,2,4-triazyne derivative caused a significant increase in superoxide dismutase activity in the erythrocytes of the hens, and after 10 weeks, only at the highest dose of supplementation. After four weeks of supplementation, the group that received the highest dose of the additive showed an increase in total antioxidant potential (FRAP) in the plasma as well as in its components, i.e. uric acid and vitamin C. After 10 weeks of supplementation a decrease was recorded in the FRAP value, as well as in uric acid, ascorbic acid and $\mathrm{Cu}$ concentrations in plasma. The observed growth of enzymatic and non-enzymatic antioxidants may indicate a mobilization of the antioxidant defence system. However, at the end of experiment, the significant decrease in the plasma concentration of the nonenzymatic antioxidants suggests that the body reserves were depleted.
\end{abstract}

Keywords: Amidrazone derivative, antioxidant status, FRAP, Index of rearing effectiveness

${ }^{\#}$ Corresponding author: kasiaognik@poczta.fm

\section{Introduction}

In an optimal functioning organism there exists a balance between oxidation reactions and antioxidant defence mechanisms. However, stress factors such as low or high ambient temperatures, transportation, crowding, and nutritional factors such as low digestible feed, vitamin E and Se deficiencies, the presence of heavy metals, mycotoxins and other toxicants, may have a negative impact on this antioxidant/prooxidant balance and induce oxidative stress (Mitchell \& Kettlewell, 1994; Rajman et al., 2006; Truchliński et al., 2007). In commercial poultry production, oxidative stress is connected with the deterioration of many physiological functions including health, growth, reproduction and immunity (Donkoh, 1989; Ferket \& Queresi, 1992; Siegel, 1995). The antioxidant system includes both enzymes and plenty of low-molecular antioxidants such as uric acid, ascorbic acid, bilirubin, urea, glutathione and others; presenting the total antioxidant potential of plasma (FRAP). It has been experimentally proven that some compounds such as amidrazone derivatives may stimulate antioxidant defence reactions. Amidrazone derivatives, such as the newly-synthesised 5-oxo-1,2,4-triazyne and 1,2,4-triazole derivative have a multidirectional pharmacological activity. Research suggested that they possess antiviral, antibacterial (against 15 bacterial strains, both Gramand $\mathrm{Gram}+$ ), antifungal (against Candida albicans), analgesic, anti-inflammatory (Modzelewska- 
Banachiewicz \& Kamińska, 2000; 2001) and immune-modulating properties (Sembratowicz et al., 2004; Krauze, 2007; Ognik \& Sembratowicz, 2009). The amidrazones are aromatic compounds containing pirydine rings. Such substances, for example nitroxides, may reveal superoxide dismutase (SOD, EC 1.15.1.1) activity, undergoing a cyclic reduction and oxidation by superoxide radicals (Bartosz, 2004). Furthermore, ions of transition metals, for example $\mathrm{Fe}^{+2}$ to $\mathrm{Fe}^{+3}$, prevent the Fenton's reaction in this way. In vitro experiments demonstrated an absence of toxic actions of the 5-oxo-1,2,4-triazyne derivative on human and mouse fibroblasts, green-monkey kidney cells and microflora of the human digestive tract (Truchliński et al., 2000; Modzelewska-Banachiewicz \& Szcześniak, 2001). The results of in vivo studies on 5-oxo-1,2,4triazyne derivatives confirmed the absence of toxicity effects in rats and mice (Modzelewska-Banachiewicz et al., 2000), thus qualifying the compound for experimentation on slaughter animals. In experiments conducted by Ognik et al. (2004) it was found that one of the amidrazone derivatives, 1,2,4-triazole, stimulates the antioxidant system in turkeys.

Considering this data, the aim of the present investigation was to evaluate the effect of different levels of the 5-oxo-1,2,4-triazyne derivative on some enzymatic and non-enzymatic antioxidant parameters in the blood of turkey hens and some performance indices of the hens.

\section{Materials and Methods}

The experiment was carried out on 240 six-week old Big- 6 turkey hens. They were divided randomly into four groups (60 birds per group), with each group consisting of three replicates of 20 birds per pen. Group I was the control. The hens in group II received $15 \mu \mathrm{g}$ of 5-oxo-1,2,4-triazyne derivative/kg body weight (BW) per day, those in group III, $30 \mu \mathrm{g}$ triazyne/kg BW/day and those in group IV, $45 \mu \mathrm{g}$ triazyne/kg

Table 1 The ingredient and nutrient composition of the experimental diets at different growth stages

\begin{tabular}{lccc}
\hline \multicolumn{1}{c}{ Feeding period } & $\begin{array}{c}\text { Grower } 1 \\
(6-9 \text { week })\end{array}$ & $\begin{array}{c}\text { Grower } 2 \\
(10-13 \text { week })\end{array}$ & $\begin{array}{c}\text { Finisher 1 } \\
(14-17 \text { week })\end{array}$ \\
\hline Ingredient & & & \\
Maize, \% & 25 & 25 & 20 \\
Wheat, \% & 30.6 & 36.8 & 56.6 \\
Soybean, \% & 33.5 & 28.0 & 15.0 \\
Meat and bone meal, \% & 5 & 5 & 4.0 \\
Soya oil, \% & 2.0 & 2.0 & 1.2 \\
Limestone, \% & 0.7 & 0.5 & 0.5 \\
Cytromix Plus, \% & 0.2 & 0.2 & 0.2 \\
Farmix, \% & 3.0 & 2.5 & 2.5 \\
Nutrient composition (calculated) & & & \\
Crude protein, mg/kg & 230 & 195 & 170 \\
Metabolizable energy, MJ/kg & 12.1 & 12.3 & 12.6 \\
Lysine, mg/kg & 14.5 & 12.5 & 10.5 \\
Methionine + Cysteine, $\mathrm{mg} / \mathrm{kg}$ & 9.5 & 8.5 & 7.5 \\
Tryptophan, mg/kg & 2.5 & 2.1 & 1.8 \\
Threonine, $\mathrm{mg} / \mathrm{kg}$ & 9.2 & 7.9 & 6.7 \\
Calcium, mg/kg & 12.0 & 11.5 & 11.0 \\
Phosphorus, mg.kg & 6.5 & 5.5 & 5.0 \\
Sodium, mg/kg & 1.5 & 1.5 & 1.5
\end{tabular}

Cytromix Plus - citric acid, fumaric acid, phosphoric acid (62\%).

Farmix - mineral and vitamin premix/kg diet: $3000000 \mathrm{IU}$ vitamin A; $900000 \mathrm{IU}$ vitamin $\mathrm{D}_{3} ; 10000 \mathrm{mg}$ vitamin E; $500 \mathrm{mg}$ vitamin $\mathrm{K}_{3} ; 700 \mathrm{mg}$ vitamin $\mathrm{B}_{1} ; 2000 \mathrm{mg}$ riboflavin; $1200 \mathrm{mg}$ vitamin $\mathrm{B}_{6} ; 6 \mathrm{mg}$ vitamin $\mathrm{B}_{12} ; 400 \mathrm{mg}$ folic acid; $72 \mathrm{mg}$ biotin; $15000 \mathrm{mg}$ niacin; $120000 \mathrm{mg}$ choline; $4200 \mathrm{mg}$ calcium pantothenic; $30000 \mathrm{mg} \mathrm{Mn}$; 18000 mg Zn; 12000 mg Fe ; 3000 mg Cu ; 200 mg I; 60 mg Se; 40 mg Co; 15 g Ca. 
BW/day. The study lasted for 10 weeks, though a two-week break with no triazyne supplementation was given in the middle of that period. The 5-oxo-1,2,4-triazyne derivative was added to the drinking water and the hens were housed under standard rearing conditions. The diets and drinking water were provided ad libitum. The 5-oxo-1,2,4-triazyne derivative was manufactured by the Department of Organic Chemistry, Pharmacological Faculty, Medical University in Lublin, Poland. The dietary ingredient and nutrient composition of the basic diets at the different growth stages of the study are presented in Table 1.

At the end of weeks 3, 5 and 9 of the experimental period, blood was collected from the wing veins of $10 \mathrm{birds} /$ group into tubes containing heparin. The concentrations of $\mathrm{Fe}, \mathrm{Zn}$ and $\mathrm{Cu}$ in plasma were determined using atomic absorption spectrophotometry on a UNICAM 939 spectrometer and the method of Iris et al. (1996) was used to measure the ferric-reducing ability of plasma (FRAP). The reaction, including 2,6-dichlorophenylindophenol (Omaye et al., 1979), was activated to measure the concentration of vitamin C in the plasma, and a commercial test kit (Cormay, Lublin, Poland) was used to measure uric acid concentration. Glutatione peroxidase (GSH-Px, EC 1.11.1.9) activity in erythrocytes was determined by using a ready-made Ransol kit from Randox (Randox Laboratories Ltd., UK) and catalase (CAT, EC 1.11.1.6) activity was determined in the erythrocytes, using the kit provided by the Oxis company (Oxis International Inc., USA). The determination of SOD activity was obtained by means of the epinephrine method according to Misra and Fridovich (Bartosz, 2004). Antioxidant enzyme activity in red blood cells (RBC) was calculated per unit of haemoglobin $(\mathrm{Hb})$, the concentration of which was obtained using the colorimetric method of Drabkins (Sanderink \& Van Rijn, 1985). Malonyl dialdehyde (MDA) concentration in plasma, as the last product of lipid peroxidation, was measured according to the Ledwożyw et al. (1986) method.

During the study, the BW at the start of the experiment and at weeks 3, 5 and 9, and the feed conversion ratio (FCR) were recorded. Based on these production measurements, an Index of Rearing Effectiveness (WEO) was calculated.

$$
\mathrm{WEO}=\frac{\text { Mean body weight after rearing }(\mathrm{kg}) \times \text { liveability }(\%) \times 100}{\text { Day of rearing } \times \text { feed conversion ratio }(\mathrm{kg} / \mathrm{kg})}
$$

The data were analyzed statistically, using Statistica v.6.0 software. Significant differences between mean values were estimated by means of a single-factorial variance analysis ANOVA, using Duncan's multiple range test, assuming significance at 0.05 (SAS, 1996). In order to compare the different levels in the treatments, the data were subjected to the regression analysis procedure (simple linear regression with groups).

\section{Results and Discussion}

A regression analysis indicated the lack of linear dependence between magnitude of dose of the 5-oxo1,2,4-triazyne derivative and tested blood and performance indices (the values of determination coefficients $-\mathrm{R}^{2}$, did not exceed 0.6). Only the relation between the level of 5-oxo-1,2,4-triazyne derivative additive and $\mathrm{Cu}$ concentration in plasma was linear, at $\mathrm{R}^{2}=0.742$. Thus, only the results of ANOVA analyses are discussed.

The results of the antioxidant measurements in the blood of the turkey hens are presented in Table 2 . Three of the enzymes that play a prominent role as antioxidants in the body are SOD, CAT and GSH-Px. However, there was no significant difference between treatments in the activity of CAT and GSH-Px in the erythrocytes of the birds (Table 2), though the supplementation of the 5-oxo-1,2,4-triazyne derivative caused an increase $(P<0.05)$ in SOD activity. This was observed after four weeks in all experimental groups, but after 10 weeks only at the highest dose of supplementation. The interruption in supplementation at the eleventh week of life resulted in a decrease in SOD activity, but this was not statistically significant. In the hens that received the highest level of the 5-oxo-1,2,4-triazyne derivative, an increase $(P<0.05)$ in FRAP was recorded after four weeks of supplementation. However, when supplementation was restarted, the response in FRAP was significantly smaller compared to the control birds. Changes in FRAP correlated with changes in the plasma concentration of its components, viz. vitamin $\mathrm{C}$ and uric acid. In the plasma of the hens that received the highest level of 5-oxo-1,2,4-triazyne, vitamin $\mathrm{C}$ and uric acid concentrations were considerably $(P<0.05)$ higher in comparison with those in the control group. After the two-week interruption in supplementation, the level of ascorbic acid was similar in all the treatment groups. At week 10 the 
concentrations of vitamin $\mathrm{C}$ and uric acid in the plasma of all treatments receiving the 5-oxo-1,2,4-triazyne, were lower $(P<0.05)$ than in the control.

One of the parameters indicating the intensity at which the oxidation processes occur in the body, is malonyl dialdehyde (MDA), the last product in the oxidation of unsaturated fatty acids. The administration

Table 2a Effect of the 5-oxo-1,2,4-triazyne derivative on the level and activity of antioxidants in the blood of turkeys

\begin{tabular}{|c|c|c|c|c|c|c|}
\hline \multirow{3}{*}{ Antioxidant } & \multirow{3}{*}{$\begin{array}{l}\text { Age in } \\
\text { weeks }\end{array}$} & \multicolumn{4}{|c|}{ Treatments } & \multirow{3}{*}{ SEM } \\
\hline & & \multirow{2}{*}{ Control } & \multicolumn{3}{|c|}{ Control + 5-oxo-1,2,4-triazyne } & \\
\hline & & & $15 \mu \mathrm{g} / \mathrm{kg} \mathrm{BW} / \mathrm{d}$ & $30 \mu \mathrm{g} / \mathrm{kg} \mathrm{BW} / \mathrm{d}$ & $45 \mu \mathrm{g} / \mathrm{kg} \mathrm{BW} / \mathrm{d}$ & \\
\hline \multirow{4}{*}{$\begin{array}{l}\mathrm{SOD} \\
\mathrm{Ug} / \mathrm{Hb}\end{array}$} & 9 & $459.9^{\mathrm{b}}$ & $518.8^{\mathrm{a}}$ & $530.6^{\mathrm{a}}$ & $527.0^{\mathrm{a}}$ & 10.25 \\
\hline & 11 & 483.0 & 512.8 & 522.5 & 516.0 & 8.25 \\
\hline & 15 & $469.7^{\mathrm{b}}$ & $514.9^{\mathrm{ab}}$ & 529.0 & $530.4^{\mathrm{a}}$ & 10.79 \\
\hline & $9-15$ & 471.2 & 515.6 & 527.4 & 534.5 & 5.57 \\
\hline \multirow{4}{*}{$\begin{array}{l}\text { GSH-Px } \\
\text { U g/Hb }\end{array}$} & 9 & $5, .9$ & 5.27 & 5.31 & 5.28 & 0.15 \\
\hline & 11 & 5.10 & 5.18 & 5.10 & 5.27 & 0.13 \\
\hline & 15 & 5.41 & 5.68 & 6.79 & 6.68 & 0.21 \\
\hline & $9-15$ & 5.24 & 5.83 & 5.74 & 5.75 & 0.11 \\
\hline \multirow{4}{*}{$\begin{array}{l}\mathrm{CAT} \\
\mathrm{Ug} / \mathrm{Hb}\end{array}$} & 9 & 1163.3 & 1168.7 & 1175.5 & 1234.9 & 19.28 \\
\hline & 11 & 1206.4 & 1194.6 & 1221.5 & 1229.3 & 24.28 \\
\hline & 15 & 1257.8 & 1229.9 & 1235.7 & 1227.1 & 17.02 \\
\hline & $9-15$ & 1209.2 & 1197.8 & 1211.0 & 1230.5 & 11.91 \\
\hline \multirow{4}{*}{$\begin{array}{l}\text { FRAP } \\
\mu \mathrm{mol} / \mathrm{L}\end{array}$} & 9 & $218.7^{b}$ & $226.9^{a b}$ & $237.1^{\mathrm{ab}}$ & $247.8^{\mathrm{a}}$ & 5.40 \\
\hline & 11 & 237.4 & 230.5 & 221.8 & 219.8 & 13.54 \\
\hline & 15 & $231.2^{\mathrm{a}}$ & $199.0^{\mathrm{b}}$ & $189.5^{b}$ & $200.0^{\mathrm{ab}}$ & 59.7 \\
\hline & $9-15$ & 229.2 & 220.5 & 216.2 & 222.4 & 5.40 \\
\hline \multirow{4}{*}{$\begin{array}{l}\text { Vitamin C } \\
\mathrm{mg} / \mathrm{L}\end{array}$} & 9 & $0.16^{\mathrm{b}}$ & $0.16^{\mathrm{b}}$ & $0.2^{\mathrm{ab}}$ & $0.21^{\mathrm{a}}$ & 0.007 \\
\hline & 11 & 0.18 & 0.14 & 0.13 & 0.15 & 0.012 \\
\hline & 15 & $0.21^{\mathrm{a}}$ & $0.11^{b}$ & $0.13^{b}$ & $0.10^{\mathrm{b}}$ & 0.013 \\
\hline & $9-15$ & 0.54 & 0.49 & 0.51 & 0.50 & 0.066 \\
\hline \multirow{4}{*}{$\begin{array}{l}\text { Uric acid } \\
\mathrm{mmol} / \mathrm{L}\end{array}$} & 9 & $0.35^{\mathrm{b}}$ & $0.39^{\mathrm{ab}}$ & $0.40^{\mathrm{ab}}$ & $0.42^{\mathrm{a}}$ & 0.009 \\
\hline & 11 & $0.47^{\mathrm{ab}}$ & $0.44^{\mathrm{b}}$ & $0.43^{\mathrm{b}}$ & $0.51^{\mathrm{a}}$ & 0.01 \\
\hline & 15 & $0.46^{\mathrm{a}}$ & $0.37^{\mathrm{b}}$ & $0.36^{\mathrm{b}}$ & $0.35^{\mathrm{b}}$ & 0.012 \\
\hline & $9-15$ & 0.43 & 0.40 & 0.40 & 0.43 & 0.008 \\
\hline \multirow{4}{*}{$\begin{array}{l}\mathrm{MDA} \\
\mu \mathrm{mol} / \mathrm{L}\end{array}$} & 9 & 1.15 & 1.13 & 1.11 & 1.15 & 0.058 \\
\hline & 11 & 1.21 & 1.20 & 1.19 & 1.18 & 0.051 \\
\hline & 15 & 1.15 & 1.17 & 1.19 & 1.18 & 0.043 \\
\hline & $9-15$ & 1.17 & 1.17 & 1.16 & 1.17 & 0.032 \\
\hline
\end{tabular}

${ }_{\mathrm{a}, \mathrm{b}}$ Row means with different superscripts differ significantly $(P \leq 0,05)$; SEM - standard error of mean. BW - body weight; SOD - super oxide dismutase; GSH-Px - glutathione peroxidise; Hb - haemoglobin; CAT catalase; FRAP - ferric reducing ability of plasma; MDA - malonyl dialdehyde. 
Table 2b Effect (regression equation) of the 5-oxo-1,2,4-triazyne derivative on the level and activity of antioxidants $(\mathrm{Y})$ in the blood of turkeys

\begin{tabular}{|c|c|c|c|}
\hline $\begin{array}{l}\text { Antioxidant } \\
\text { (Y) }\end{array}$ & $\begin{array}{l}\text { Age in } \\
\text { weeks }\end{array}$ & $\mathrm{R}^{2}$ & Regression equation \\
\hline \multirow{4}{*}{$\begin{array}{l}\mathrm{SOD} \\
\mathrm{Ug} \text { /Hb }\end{array}$} & 9 & 40.7 & $\mathrm{Y}=1.4215 \mathrm{x}+477.14$ \\
\hline & 11 & 10.9 & $Y=0.7089 x+492.88$ \\
\hline & 15 & 21.7 & $Y=1.3079 x+481.61$ \\
\hline & $9-15$ & 27.7 & $Y=0.0525 x^{2}+3.5095 x+472$ \\
\hline \multirow{4}{*}{$\begin{array}{l}\text { GSH-Px } \\
\text { U g/Hb }\end{array}$} & 9 & 0.38 & $\mathrm{Y}=0.0019 \mathrm{x}+5.2212$ \\
\hline & 11 & 0.68 & $Y=0.0028 x+5.1042$ \\
\hline & 15 & 36.1 & $Y=0.0327 x+5.4097$ \\
\hline & $9-15$ & 0.61 & $Y=0.0002 x^{2}+0.0193 x+5.2109$ \\
\hline \multirow{4}{*}{$\begin{array}{l}\text { CAT } \\
\mathrm{Ug} \text { /Hb }\end{array}$} & 9 & 20.1 & $Y=1.4776 x+1152.4$ \\
\hline & 11 & 1.5 & $Y=0.6385 x+1198.6$ \\
\hline & 15 & 1.6 & $Y=-0.5736 x+1250.6$ \\
\hline & $9-15$ & 1.1 & $\mathrm{Y}=0.0344 \mathrm{x}^{2}-1.0335+1208.3$ \\
\hline \multirow{4}{*}{$\begin{array}{l}\text { FRAP } \\
\mu \mathrm{mol} / \mathrm{L}\end{array}$} & 9 & 2.1 & $Y=0.6378 x+218.19$ \\
\hline & 11 & 1.5 & $Y=-0.4439 x+238.68$ \\
\hline & 15 & 17.3 & $Y=218.06 e-0.0031 x$ \\
\hline & $9-15$ & 1.2 & $Y=0.0165 x^{2}-0.9055 x+229.47$ \\
\hline \multirow{4}{*}{$\begin{array}{l}\text { Vitamin C } \\
\mathrm{mg} / \mathrm{L}\end{array}$} & 9 & 34.2 & $Y=0.0011 x+0.1596$ \\
\hline & 11 & 11.8 & $Y=7 E-0,5 x^{2}-0.0035 x+0.1813$ \\
\hline & 15 & 0.7 & $Y=0.0009+1.1549$ \\
\hline & $9-15$ & 0.06 & $Y=4 E-0.5 x^{2}-0.0022 x+0.5297$ \\
\hline \multirow{4}{*}{$\begin{array}{l}\text { Uric acid } \\
\mathrm{mmol} / \mathrm{L}\end{array}$} & 9 & 55.2 & $Y=0.0017 x+0.3542$ \\
\hline & 11 & 9.1 & $Y=0.0008 x+0.448$ \\
\hline & 15 & 59.1 & $Y=0.4394 e-0.006 x$ \\
\hline & $9-15$ & 0.74 & $Y=7 E-0.5 x^{2}-0.0031 x+0.4304$ \\
\hline \multirow{4}{*}{$\begin{array}{l}\mathrm{MDA} \\
\mu \mathrm{mol} / \mathrm{L}\end{array}$} & 9 & 0.37 & $Y=-7 E-0.5 x^{2}-0.0032 x+1.1582$ \\
\hline & 11 & 0.34 & $Y=-0.0008 x+1.2154$ \\
\hline & 15 & 44.1 & $Y=0.1815 e-0.014 x$ \\
\hline & $9-15$ & 0.03 & $Y=4 E-0.5 x^{2}-0.0015 x+0.8293$ \\
\hline
\end{tabular}

SOD - super oxide dismutase; GSH-Px - glutathione peroxidise; Hb - haemoglobin; CAT - catalase; FRAP - ferric reducing ability of plasma; MDA - malonyl dialdehyde.

Regression is based on values obtained at different levels of the 5-oxo-1,2,4-triazyne derivative (x) application. $\mathrm{R}^{2}$ - coefficient of determination.

of the 5-oxo-1,2,4-triazyne derivative to turkey hens did not affect the MDA concentration in the plasma of the birds. The proper functioning of antioxidant enzymes depends on the optimal concentrations of $\mathrm{Mn}, \mathrm{Cu}$, $\mathrm{Zn}$ and Fe in the blood. These elements play a role as cofactors in these enzyme activities and a deficiency in them tends to increase the activity of antioxidant enzymes (Bertinato et al., 2003; Ognik et al., 2004). 
Table 3 The effect of the 5-oxo-1,2,4-triazyne derivative on the mineral element concentration in the blood plasma of turkeys

\begin{tabular}{|c|c|c|c|c|c|c|c|c|}
\hline \multirow{3}{*}{$\begin{array}{l}\text { Mineral } \\
\text { elements }\end{array}$} & \multirow{3}{*}{$\begin{array}{l}\text { Age in } \\
\text { weeks }\end{array}$} & \multicolumn{4}{|c|}{ Treatments } & \multirow{3}{*}{ SEM } & \multirow{3}{*}{$\begin{array}{c}\mathrm{R}^{2} \\
{[\%]}\end{array}$} & \multirow{3}{*}{ Regression equation } \\
\hline & & \multirow{2}{*}{ Control } & \multicolumn{3}{|c|}{ Control + 5-oxo-1,2,4-triazyne } & & & \\
\hline & & & $15 \mu \mathrm{g} / \mathrm{kg} \mathrm{BW} / \mathrm{d}$ & $30 \mu \mathrm{g} / \mathrm{kg} \mathrm{BW} / \mathrm{d}$ & $45 \mu \mathrm{g} / \mathrm{kg} \mathrm{BW} / \mathrm{d}$ & & & \\
\hline \multirow{4}{*}{$\begin{array}{l}\text { Iron } \\
\mathrm{mmol} / \mathrm{L}\end{array}$} & 9 & 31.7 & 30.6 & 33.3 & 33.6 & 0.26 & 32.4 & $\mathrm{Y}=0.0563 \mathrm{x}+31.078$ \\
\hline & 11 & 32.7 & 31.3 & 33.1 & 33.5 & 0.34 & 20.1 & $Y=0.0021 x^{2}-0.0671 x+32.56$ \\
\hline & 15 & 34.4 & 33.8 & 35.6 & 32.6 & 0.35 & 20.5 & $Y=-0,0026 x^{2}+0.0928 x+34.048$ \\
\hline & $9-15$ & 32.97 & 31.95 & 33.99 & 33.30 & 0.225 & 4.1 & $Y=0.0004 x^{2}+0.0037 x+32.679$ \\
\hline \multirow{4}{*}{$\begin{array}{l}\text { Zinc } \\
\mathrm{mmol} / \mathrm{L}\end{array}$} & 9 & 28.1 & 26.7 & 27.0 & 27.2 & 0.26 & 4.9 & $Y=-0.0152 x+27.652$ \\
\hline & 11 & 29.3 & 27.8 & 30.4 & 30.1 & 0.36 & 12.3 & $Y=0.0327 x+28.68$ \\
\hline & 15 & 30.3 & 31.0 & 29.9 & 29.2 & 0.27 & 25.2 & $Y=-0.0014 x^{2}+0.0347 x+30.46$ \\
\hline & $9-15$ & 29.27 & 28.53 & 29.12 & 28.87 & 0.23 & 0.61 & $Y=0.005 x^{2}-0.0283 x+29.159$ \\
\hline \multirow{4}{*}{$\begin{array}{l}\text { Copper } \\
\mathrm{mmol} / \mathrm{L}\end{array}$} & 9 & 20.8 & 20.2 & 19.3 & 18.2 & 0.26 & 74.2 & $Y=-0.057 x+20.968$ \\
\hline & 11 & 21.6 & 20.7 & 20.5 & 19.9 & 0.20 & 40.8 & $Y=-0.0324 x+21.404$ \\
\hline & 15 & $23.8^{\mathrm{a}}$ & $20.4^{\mathrm{b}}$ & $20.2^{\mathrm{b}}$ & $20.0^{\mathrm{b}}$ & 0.38 & 25.2 & $Y=-0.0014 x^{2}+0.0347+30.46$ \\
\hline & $9-15$ & 22.05 & 20.44 & 20.06 & 19.41 & 0.18 & 47.5 & $Y=0.0011 x^{2}-0.1032 x+21.972$ \\
\hline
\end{tabular}

${ }^{\mathrm{a}, \mathrm{b}}$ Row means with different superscripts differ significantly $(P<0.05)$; SEM - standard error of mean.

Regression is based on values obtained at different levels of the 5-oxo-1,2,4-triazyne derivative (x) application.

$\mathrm{R}^{2}$ - coefficient of determination.

BW - body weight. 
Table 4 The effect of the 5-oxo-1,2,4-triazyne derivative on the performance indices of turkey hens' body weight (BW) gains calculated and included instead of body weight. Feed conversion ratio (FCR) calculated and included in all periods (7-10, 11-12, 13-16 weeks)

\begin{tabular}{|c|c|c|c|c|c|c|c|}
\hline & \multicolumn{4}{|c|}{ Treatments } & \multirow{3}{*}{ SEM } & \multirow{3}{*}{$\begin{array}{c}\mathrm{R}^{2} \\
{[\%]}\end{array}$} & \multirow{3}{*}{ Regression equation } \\
\hline & \multirow{2}{*}{ Control } & \multicolumn{3}{|c|}{ Control + 5-oxo-1,2,4-triazyne } & & & \\
\hline & & $15 \mu \mathrm{g} / \mathrm{kg} \mathrm{BW} / \mathrm{d}$ & $30 \mu \mathrm{g} / \mathrm{kg} \mathrm{BW} / \mathrm{d}$ & $45 \mu \mathrm{g} / \mathrm{kg} \mathrm{BW} / \mathrm{d}$ & & & \\
\hline \multicolumn{8}{|c|}{ Body weight (BW, kg) } \\
\hline $6^{\text {th }}$ week & 1.75 & 1.69 & 1.73 & 1.72 & 0.009 & 0.75 & $Y=-0.0002 x+1.7293$ \\
\hline $9^{\text {th }}$ week & 3.58 & 3.78 & 3.80 & 3.80 & 0.059 & 9.1 & $Y=0.0047 x+3.6408$ \\
\hline $11^{\text {th }}$ week & $4.83^{\mathrm{b}}$ & $5.25^{\mathrm{ab}}$ & $5.29^{\mathrm{a}}$ & $5.05^{\mathrm{ab}}$ & 0.08 & 27.1 & $Y=0.0047 x+5.001$ \\
\hline $15^{\text {th }}$ week & 7.84 & 8.29 & 8.23 & 8.16 & 0.11 & 4.1 & $Y=0.0058 x+8.0036$ \\
\hline $\begin{array}{l}\text { FCR, }(\mathrm{kg} / \mathrm{kg}) \\
6-15 \text { weeks }\end{array}$ & 2.58 & 2.52 & 2.49 & 2.53 & 0.01 & & \\
\hline WEO, points & 394.7 & 427.3 & 429.3 & 418.9 & 3.93 & & \\
\hline
\end{tabular}

a, b - Row means with different superscripts differ significantly $(P<0,05)$;

SEM - standard error of mean.

Regression is based on the values obtained at different levels of the 5-oxo-1,2,4-triazyne derivative (x) application.

$\mathrm{R}^{2}$ - coefficient of determination; WEO - Index of Rearing Effectiveness. 
The results presented in Table 3 indicate no significant differences among the groups in relation to $\mathrm{Fe}$ and $\mathrm{Zn}$ concentration in plasma. However, the administration of the 5-oxo-1,2,4-triazyne derivative caused a significant decrease of $\mathrm{Cu}$ concentration in the plasma of the birds at the end of the experiment.

An increase in enzymatic activity and non-enzymatic concentrations of antioxidants may indicate a mobilization of the antioxidant defence system in the body. However, a significant decrease in their values, especially in the non-enzymatic antioxidants, FRAP, uric acid, vitamin $\mathrm{C}$ and $\mathrm{Cu}$ concentrations at the end of the experiment, suggests that they were depleted. According to Bartosz (2004) the increase in the concentration of low molecular antioxidants such as uric acid, which constitutes up to $60 \%$ of FRAP, may be used as an oxidative stress indicator, because it probably reflects an adaptive response from the body. The observed increase of erythrocyte SOD activity may also indicate the probability of an occurrence of oxidation stress. It is known that SOD is an enzyme that depends mainly on a degree of free radical diffusion which is generated mostly during infection, inflammation and stress (Finkel \& Holbrook, 2000). The drop in $\mathrm{Cu}$ concentration in plasma is connected with the increase of SOD activity, because it is a cofactor of SOD. When SOD activity is increased, $\mathrm{Cu}$ reserves might become depleted, especially if deficient in the diet. The interrelationship between the $\mathrm{Cu}$ concentration in the plasma and the SOD activity in erythrocytes has been demonstrated in experiments on animals and humans (Jones et al., 1997; Ogryczak et al., 2001; Bertinato et al., 2003). An increased SOD activity in the plasma of turkey hens that received a product similar to the 1,2,4-triazole derivative, was recorded by Ognik et al. (2004). Because the increase in SOD activity was not related to an increase in GSH-Px or CAT activity in the erythrocytes and in the MDA level in plasma, it is difficult to conclude that the 5-oxo-1,2,4-triazyne derivative possesses prooxidant properties, or whether these observed changes in antioxidant parameters are the result of the stimulation of the antioxidant system. No changes in MDA level or GSH-Px activity were noted in another experiment where turkey hens were stressed through crowding (Truchliński et al., 2007). The elevation of SOD, GSH-Px and CAT activity as well as non-enzymatic antioxidants was observed in turkey hens which received natural biostimulant preparations (Ognik \& Sembratowicz, 2007). There are reports which indicate that some preparations or drugs, for example cytostatic ones, stimulate the antioxidant system through a direct effect on the genome (Noroozi et al., 1998; Konopacka, 2004). Therefore, it cannot be excluded that these synthetised amidrazones derivatives, such as the 5-oxo-1,2,4-triazyne derivative, may act in this way.

Performance data presented in Table 4 reveal that, at the eleventh week of rearing, the addition of 30 $\mu \mathrm{g}$ of the 5-oxo-1,2,4-triazyne derivative/ $\mathrm{kg}$ BW/day to the hens' diet resulted in a higher $(P<0.05) \mathrm{BW}$ than the control. Generally, during all experimental periods, the birds on the treatments of the 5-oxo-1,2,4triazyne derivative were heavier than the hens in the control. Likewise, the Index of WEO in all supplemented groups was higher, though not significantly more than that of the control.

The findings in this study are consistent with those of Sembratowicz et al. (2004) who reported insignificant improvement performance indices of turkey hens that received a high dose of 5-oxo-1,2,4triazyne $(100 \mu \mathrm{g} / \mu \mathrm{g} / \mathrm{kg} \mathrm{BW} /$ day $)$. Slightly better results of rearing, achieved in the experimental groups, might be the result of bacteriostatic and antiviral properties of that compound (Modzelewska-Banachiewicz \& Kamińska, 2001).

\section{Conclusions}

Supplementation of different levels of the 5-oxo-1,2,4-triazyne derivative to the diets of turkey hens had no significant effect on performance indices, except for BW at 11 weeks of age, at the supplementation rate of $30 \mu \mathrm{g} / \mathrm{kg} \mathrm{BW} /$ day. GSH-Px and CAT activities in erythrocytes, as well as MDA, Fe and $\mathrm{Zn}$ concentrations in plasma were also not affected by triazyne supplementation. After four weeks of supplementation a significant increase in FRAP was recorded in all experimental groups, also evident in the significant increase in the concentration of components of FRAP, viz. uric acid and vitamin C. At 12 weeks this was observed only in the group supplemented with the highest dose of the 5-oxo-1,2,4-triazyne derivative. At the end of the experiment all the groups supplemented with the 5-oxo-1,2,4-triazyne showed a decrease in these indices in the blood.

The observed changes in the analysed antioxidant parameters after the 5-oxo-1,2,4-triazyne derivative supplementation was administered, indicate the necessity for further research on this compound. In order to verify the obtained results it is necessary to broaden the range of analyses of other parameters that indicate the intensity of the peroxidizing processes, such as peroxides, lipid hydroperoxides and conjugated dienes. 


\section{References}

Bartosz, G., 2004. Second face of oxygen. PWN, Warszawa (in Polish).

Bertinato, J., Iskander, M. \& L-Abbe, M.R., 2003. Copper deficiency induces the upregulation of the copper chaperone for $\mathrm{Cu} / \mathrm{Zn}$ superoxide dismutase in weanling male rats. J. Nutr. 133, 28-31.

Donkoh, A., 1989. Ambient temperature: a factor affecting performance and physiological response of broiler chickens. Int. J. Biometeorol. 33, 259-265.

Ferket, P.R. \& Queresi, M.A., 1992. Performance and immunity of heat-stressed broilers fed vitamin E and electrolyte supplemented drinking water. Poult. Sci. 71, 88-97.

Finkel, T. \& Holbrook, N.J., 2000. Oxidants, oxidative stress and the biology of ageing. Nature 408, 239-247.

Iris, F., Benzie, F. \& Strain, J.J., 1996. The ferric reducing ability of plasma (FRAP) as a measure of antioxidant power: The FRAP assay. Anal. Biochem. 239, 70-76.

Jones, A.A., Di Silvestro, R.A., Coleman, M.M. \& Wagner, T.L., 1997. Copper supplementation of adult men: Effects on blood copper enzyme activities and indicators of cardiovascular disease risk. Metab. $12,1380-1383$.

Konopacka, M., 2004. Role of the vitamin C in oxidizing and damage of DNA. Post. Hig. Med. Dośw. 58, 343-348. (in Polish, English abstract).

Krauze, M., 2007. Influence of differentiated rations of 1,2,4-triasole derivative on the level of chosen blood indicators and rearing efficiency of slaughter turkey-hens. Ann. UMCS, s. DD. 1, 8-14.

Ledwożyw, A., Michalak, J., Stępień, A. \& Kędziołka, A., 1986. The relationship between plasma triglicerydes, cholesterol, total lipids and lipid peroxidation products during human atherosclerosis. Clin. Chem. Acta. 155, 275-284.

Mitchell, M.A. \& Kettlewell, P.J., 1994. Road transportation of broiler chickens - induction of physiological stress. Wrld's Poult. Sci. J. 50, 57-59.

Modzelewska-Banachiewicz, B. \& Kamińska, T., 2000. Synthesis and biological action of 5-oxo-1,2,4triazyne derivatives. Pharmazie 54, 503-505.

Modzelewska-Banachiewicz, B. \& Kamińska, T., 2001. Antiviral activity of cyclization of dimethyl 2-[(1arylamino-1-arylmethylidene) hydrazono] succinate. Eur. J. Med. Chem. 36, 93-99.

Modzelewska-Banachiewicz, B. \& Szcześniak, Z., 2001. The influence of 1, 2, 4-triazyne derivatives on some species of the human digestive tract microflora. Ann. UMCS, s. DDD. 14, 9-11.

Modzelewska-Banachiewicz, B., Jagiełło-Wójtowicz, E. \& Tokarzewska-Wielosz, E., 2000. Synthesis and biological activity of bis-1,2,4-triazole and bis-1,3,4-thiadiazole derivatives. Acta Pol. Pharm.- Drug Res. 57 (3), 199-204.

Noroozi, M., Angerson, W.J. \& Lean, M.E.J., 1998. Effects of flavonoids and vitamin C on oxidative damage in human lymphocytes. Am. J. Clin. Nutr. 7, 1210-1217.

Ognik, K. \& Sembratowicz, I., 2007. Influence of Biostymina and Bioaron C on some anti-oxidation and immune indices of turkey-hens' blood. Pol. J. Environ. St. 16, 3A, 209-212.

Ognik, K. \& Sembratowicz, I., 2009. Influence of synthesized 5-oxo-1,2,4-triazyne derivative on some immunological and hematological indices of turkey. J. Appl. Anim. Res., 13, 235-237.

Ognik, K., Sembratowicz, I. \& Modzelewska-Banachiewicz, B., 2004. Concentrations of selected elements and activities of anti-oxidation enzymes in blood of turkey hens given Echinovit $\mathrm{C}$ and 1,2,4-triazole derivative. J. Element. 9 (3), 445-449.

Ogryczak, D., Jurek, A., Kleczkowski, M., Kluciński, W., Sitarska, E., Sikora, J., Kasztelan, R. \& Shaktur, A., 2001. Activity of superoxide dismutase characteristic in cow's blood reflects different demands for mineral elements. Biul. Magn. 6, 4, 616-622. (in Polish, English abstract).

Omaye, S.T., Turnbull, J.D. \& Sauberlich, H.E., 1979. Selected methods for determination of ascorbic acid in animal cells, tissues and fluids. Meth. Enzymol. 62, 3-11.

Rajman, M., Juráni, M., Lamosová, D., Mácajová, M., Sedlacková, M., Kost'ál, L., Jezová, D. \& Výboh, P., 2006. The effects of feed restriction on plasma biochemistry in growing meat type chickens (Gallus gallus). Comp. Biochem. Physiol. 145, 363-371.

Randox Laboratories Ltd., Ardmore, Diamond Road, Crumlin, Co. Antrim, United Kingdom, BT29 4QY; Tel: UK (028) 94452912; e-mail: applications@randox.com.

Sanderink, G.J.C.M. \& Van Rijn, H.J., 1985. Quantitative measurement of plasma hemoglobin by second derivative spectrophotometry. Clin. Chim. Acta 146, 65-73. 
SAS, 1996. Statistical Analysis System User's Guide: Statistics. (Version 6.11). SAS Inst. Inc., Cary, N.C., USA.

Sembratowicz, I., Ognik, K., Truchliński, J. \& Modzelewska-Banachiewicz, B., 2004. The Influence of 1,2,4-triazole and 5-oxo-triazyne derivatives on some indices of blood and performance of turkey hens. J. Anim. Feed Sci. 13, 39-42.

Siegel, H.S., 1995. Stress, strains, and resistance. Br. Poult. Sci. 36, 3-20.

Truchliński, J., Kifer-Wysocka, E. \& Modzelewska-Banachiewicz, B., 2000. Action of 1,2,4-triazole and 1,2,4-triazyne derivatives on cells of green Monkey kidney in vitro culture. Ann. UMCS, s. DD, 6, $37-43$.

Truchliński, J., Ognik, K. \& Sembratowicz, I., 2007. Influence of prolonged and interrupted stress in a form of crowding and cooling of turkey-hens on anti-oxidation indices of blood. Med. Wet. 1, 95-98. (in Polish, English abstract). 